\title{
Inorganic Nitrogen Fractions in Soil Under Different Uses and Management Systems in the Brazilian Eastern
}

\section{Amazon}

\author{
Camila Maciel Torres \\ Federal Rural University of Amazon, 066.077-830, Belém, Pará, Brazil \\ E-mail: camilatorres.agro@hotmail.com \\ Andresa Damaris de Souza Pinheiro \\ Federal Rural University of Amazon, 68625-970, Paragominas, Pará, Brazil. \\ E-mail: andresadamaris@ hotmail.com \\ Letícia Cunha da Hungria (Corresponding author) \\ Federal Rural University of Amazon, 066.077-830, Belém, Pará, Brazil \\ leth_hungria@hotmail.com \\ Jamil Chaar El-Husny \\ Embrapa Eastern Amazon, 66095-903, Belém, Pará, Brazil. \\ E-mail: jamil.husny@embrapa.br \\ Priscila Pereira Sacramento \\ Federal Institute of Pará, 68746-630, Castanhal, Pará, Brazil \\ E-mail: priscila.sacrame@gmail.com \\ Izabelle Pereira Andrade \\ Federal Rural University of Amazon, 68625-970, Paragominas, Pará, Brazil. \\ E-mail: izabelle.andrade@ufra.edu.br
}

Received: May 25, 2020 Accepted: July 13, $2020 \quad$ Published: July 20, 2020

doi:10.5296/jas.v8i4.17080 URL: https://doi.org/10.5296/jas.v8i4.17080

\section{Abstract}

Land use and management systems are factors that control availability and nitrogen $(\mathrm{N})$ 
forms in soil environment. The aim was to evaluate the inorganic $\mathrm{N}$ fractions dynamics in soil under different use and management systems in Brazilian Eastern Amazon conditions. Soils were sampled at depths of 0.0-0.1 and 0.1-0.2 $\mathrm{m}$ in areas under pasture (PAST), no-tillage (NT), conventional tillage (CT) and a reference area under fallow vegetation (FV). In the samples, soil organic matter $(\mathrm{SOM})$, total- $\mathrm{N}$, ammonium $\left(\mathrm{N}_{-} \mathrm{NH}_{4}{ }^{+}\right)$and nitrate $\left(\mathrm{N}_{-} \mathrm{NO}_{3}{ }^{-}\right)$ contents were determined and the urease enzyme activity was measured. In CT and NT the SOM contents were similar to those found in FV, with an average of $36.7 \mathrm{~g} \mathrm{~kg}^{-1}$, while under PAST there was a $16.6 \%$ reduction when compared to the reference area. The total-N levels followed the same dynamics found for SOM. The ammonium concentration was 2.4 times higher in soils under FV (14 $\mathrm{mg} \mathrm{kg}^{-1}$ ) when compared to other systems and nitrate followed the order NT> CT> FV=PAST. The pasture $\left(44 \mu \mathrm{g} \mathrm{N}-\mathrm{NH}_{4}{ }^{+} \mathrm{g}^{-1}\right.$ soil $\left.\mathrm{h}^{-1}\right)$, among soils for agricultural use, induced the highest ureolytic activity. The preserved soil conversion from native forest to pasture caused a $16.6 \%$ reduction in the SOM contents and 55.5\% and 46\% for ammonium and nitrate, respectively. On the other hand, the NT system has the capacity to accumulate SOM in a similar way to the area of native vegetation studied, as well as a high capacity to retain $\mathrm{N}$ in the soil, preferentially in the nitrate form.

Keywords: N dynamics, soil environment, agricultural use, ureolytic activity

\section{Introduction}

Nitrogen $(\mathrm{N})$ is one of the nutrients most required by plants, due to their participation in the molecules composition such as proteins, nucleic acids and chlorophyll, which are indispensable to the metabolic plant organisms processes (Webster et al., 2016).

In soil, the $\mathrm{N}$ total amount, in general, varies between $0.05 \%$ and $0.5 \%$, linked to several organic compounds, and in soils of tropical climates this variation occurs between $0.02 \%$ and $0.4 \%$ or until 2\% (Rangel; Silva, 2007; Siqueira Neto et al., 2010). The soil N stocks, mainly in agricultural systems, depends on the balance between the increased amounts via atmospheric $\mathrm{N}_{2}$ biological fixation, nitrogen fertilization and $\mathrm{N}$-organic mineralization and the losses caused by processes such as leaching, volatilization and harvest export (Hungria, 2018).

The $\mathrm{N}$ fraction predominantly found in the soil is complexed in the organic form, this fraction being a $\mathrm{N}$ labile forms reservoir, while less than $5 \%$ corresponds to the inorganic fractions in the ammoniacal $\left(\mathrm{NH}_{4}{ }^{+}\right)$and nitric $\left(\mathrm{NO}_{3}{ }^{-}\right)$forms, which are the forms readily available to plants and which originate, during cultivation, through enzymatic hydrolysis produced by the activity of soil microbiota and/or nitrogen fertilizers application (Cordeiro \& Hoek, 2007). These two forms are still conditioned to mineralization and immobilization processes (Cantarella, 2007; Fageria; Baligar; Jones, 2011).

During mineralization, biological conversion from organic $\mathrm{N}$ to inorganic $\mathrm{N}$ form occurs and it is estimated that annually this transformation does not exceed $3 \%$ of the soil total $\mathrm{N}$, justifying the need for nitrogen fertilizers for compensation in areas of agricultural interest. On the other hand, immobilization is the process inorganic $\mathrm{N}$ assimilation by microorganisms in the soil, which results in the reduction of available $\mathrm{N}$ forms (Campana, 2008). 


\section{MlMacrothink}

Journal of Agricultural Studies

ISSN 2166-0379

2020, Vol. 8, No. 4

The availability and $\mathrm{N}$ forms found in the soil can also be a pronounced effect of the soil organic matter (SOM) dynamics, which constitutes the active and potentially mineralizable fraction and is closely related to the $\mathrm{N}$ cycle (Lourente et al., 2016). Therefore, in soils under preserved vegetation conditions such as forest soils, for example, it may be a favorable environment for maintenance $\mathrm{N}$, since in these soils there is continuous and diversified litter deposition and absence of soil preparation that maintains stable state in the SOM additions and losses in this system. However, in altered areas, depending on the use and management system adopted, behavior different from the contents of the SOM may occur.

In no-tillage system (NT), the maintenance of cultural residues on the soil surface added to the non-revolving soil favors the increase in the SOM contents over time (Lisboa et al., 2012). In contrast, under conventional tillage (CT), the losses of the original SOM stocks, after 23 years of system implantation, can reach 50\% (Bayer et al., 2003). In pasture environments, in the first $0.3 \mathrm{~m}$ of the soil there may be an increase in the SOM supply arising from the root system of the forage plants used.

Previous studies carried out in Amazon soils on $\mathrm{N}$ fractions in different agricultural systems investigated, in particular, total N (Silva Júnior et al., 2018) and microbial N (Aragão et al., 2012; Lopes et al., 2015) for evaluation of the biological response given by the microbiota. The inorganic $\mathrm{N}$ fractions determination can help to better understand the potential $\mathrm{N}$ availability. The aim was to evaluate the inorganic $\mathrm{N}$ fractions dynamics in the soil under different use and management systems in Brazilian Eastern Amazon conditions.

\section{Material and Methods}

\subsection{Description of the Study Site}

The study was carried out at in a farm in the municipality of Paragominas, southeastern Pará, Brazilian eastern amazon, under the coordinates $02^{\circ} 55^{\prime} 24^{\prime \prime} \mathrm{S}$ and $47^{\circ} 34^{\prime} 36^{\prime \prime} \mathrm{W}$ at approximately 200 meters above sea level. The farm contains 1.379 hectare (ha) of arable area, composed of 695.6 ha of legal reserve area and 913.9 ha of alternative land use.

The region has a rainy tropical climate, Awi-type according to classification of Köppen, with an expressive drought period and the beginning of the rainy season in December, extending until May, with less water availability between June and November. The average precipitation and average annual temperature is $1.800 \mathrm{~mm}$ (average in thirty years) and $26.6{ }^{\circ} \mathrm{C}$, respectively (Rodrigues et al., 2003). The soil was classified as Yellow Oxisol, very clayey texture, with a flat, gently undulating relief characteristic of the region.

\subsection{Area Characterization and Soil Sampling}

The use and management systems considered in this study included an area under pasture (PAST), conventional tillage (CT), no-tillage (NT) and an area under fallow vegetation (FV), for comparison purposes. The descriptions of the areas are detailed in Table 1. 
Table 1. Descriptions of areas with different soil use and management

Soil use and

Description

management system

\begin{tabular}{cl}
\hline Pasture & Pasture with Brachiaria brizhanta, with 7 years of implantation. \\
\hline & $\begin{array}{l}\text { In } 2002 \text { the area was occupied by Brachiaria decumbens pasture and in } \\
2013 \text { the area was replaced by a no-tillage system with soybean } \\
\text { No-tillage }\end{array} \quad$ Glycine max).
\end{tabular}

In 2009 the area was occupied by the no-tillage system and in 2014 Conventional tillage conventional tillage with soybean was implemented.

Former rubber plantation, with approximately 35 years in natural regeneration, used as a comparative area to those under the tillage and

Fallow vegetation use systems.

Soil sampling was carried out in May 2015, at the end of the rainy season. In all areas, samples were collected at depths $0.0-0.1$ and $0.1-0.2 \mathrm{~m}$, with five replications. Twenty randomly collected subsamples were obtained to form a composite sample in each plot of all evaluated areas. Then, the samples were kept in a refrigerated environment and remained in this condition until the time of the tests. Subsequently, the soil was sieved in a $2 \mathrm{~mm}$ mesh, removing the plant fragments and prepared for analysis.

\subsection{SOM Determination and N Fractions Quantification}

Soil organic matter (SOM) was determined by the Walkey and Black (1934) method and the soil total nitrogen (total-N) was estimated by the Kjeldahl method by steam distillation. The soil inorganic-N (N-NO${ }^{-}$and $\left.\mathrm{N}^{-} \mathrm{NH}_{4}{ }^{+}\right)$extraction was carried out according to the methodology described by Cantarella and Trivelin (2001), which consists of the extraction using $\mathrm{KCl}$ solution $(1 \mathrm{M})$. The determination in the extracts was performed by the colorimetric method according to the simplified methodology proposed by Keeney (1982) and the salicylate method by Yang et al. (1998) for the $\mathrm{N}^{-\mathrm{NH}_{4}}{ }^{+}$and $\mathrm{N}-\mathrm{NO}_{3}{ }^{-}$concentrations, respectively.

\subsection{Urease Activity}

The urease activity was determined by the method described by Tabatabai \& Bremner (1972), which is based on the ammonia released determination after incubating the soil with a solution of urea, for two hours, at $37^{\circ} \mathrm{C}$. The result is expressed in $\mu \mathrm{g}$ of $\mathrm{N}_{-} \mathrm{NH}_{4}{ }^{+}$per gram of dry soil per hour.

\subsection{Data Analysis}

Statistical analyzes were performed with the aid of the STATISTICA version 10.0 program. The data for all treatments were tested for normality using the Shapiro Wilk test. Analysis of variance ( $\mathrm{F}$ test) was performed to determine the effect of different soil use and management systems and depth on soil $\mathrm{N}$ levels and forms, urease activity and SOM. When significant, means were compared by Scott Knott test at $5 \%$ probability 


\section{Results and Discussion}

\subsection{Soil Organic Matter (SOM) and Total-N}

The SOM levels were higher in the superficial layer $(0.0-0.1 \mathrm{~m})$ and reduced, on average, $30 \%$ with the increase in depth in most systems, except in soils under CT, which showed no difference between the layers $(\mathrm{p}<0.05)$. In the shallower layer $(0.0-0.1 \mathrm{~m})$, the SOM contents were similar between the systems, while in the subsurface layer (0.1-0.2 m) the highest SOM levels were recorded in soils under CT and NT, followed by FV and PAST, which did not differ significantly from each other (Table 2).

Table 2. Soil organic matter (SOM) levels $\left(\mathrm{g} \mathrm{kg}^{-1}\right)$ in two depths under fallow vegetation (FV), conventional tillage (CT), no-tillage (NT) and Pasture (PAST) in Brazilian Eastern Amazon

\begin{tabular}{cccccc}
\hline & \multicolumn{5}{c}{ Use and management system of soil } \\
\cline { 2 - 6 } Depth $(\mathrm{m})$ & $\mathrm{FV}$ & $\mathrm{CT}$ & $\mathrm{NT}$ & PAST & Mean \\
\hline $0.0-0.1$ & $44.13 \mathrm{Aa}$ & $41.01 \mathrm{Aa}$ & $40.68 \mathrm{Aa}$ & $35.17 \mathrm{Aa}$ & $40.25 \mathrm{~A}$ \\
$0.1-0.2$ & $27.56 \mathrm{Bb}$ & $35.50 \mathrm{Aa}$ & $31.20 \mathrm{Ba}$ & $24.63 \mathrm{Bb}$ & $29.72 \mathrm{~B}$ \\
Mean & $35.85 \mathrm{a}$ & $38.26 \mathrm{a}$ & $35.94 \mathrm{a}$ & $29.90 \mathrm{~b}$ & 34.99 \\
\hline
\end{tabular}

Means followed by the same uppercase letter in the column and lowercase letter in the row do not different by Scott-Knott test at 5\% probability level.

The SOM contents alterations in layers can be related by the isolated influence or several factors sum, with emphasis on the cultural residues accumulation on the soil surface, the growth and organic acids exudation from the roots and soil revolving. In areas under CT, a lower SOM contents is commonly observed in superficial layers in relation to lower depths, due to the fact that the first layers are more susceptible to oxidation and loss of $\mathrm{C}$ in this system; and more uniform vertical distribution when compared to the NT. This is mainly the result of the turning of the soil arable layer in the CT, making the SOM levels, at greater depths, be similar or even higher than in the NT system (Ussiri \& Lal, 2009).

In general, regardless of the evaluated layer, in PAST environments $\left(29.90 \mathrm{~g} \mathrm{~kg}^{-1}\right)$ the lowest mean SOM levels were found. Although several studies (Silva \& Mielniczuk, 1997; Costa et al., 2000; El-Husny, 2010) show that pasture areas, especially with Brachiaria brizantha (Cerri; Feigl; Cerri, 2008) tends to stock C in the soil, due to the great part of the root system of the grasses to be concentrated in the first meters of the soil (approximately $0.4 \mathrm{~m}$ ), which guarantees an SOM greater contribution, in this study this behavior was not observed. Thus, one must consider the quality of the organic material deposited particularities in the soil, such as lignin contents and $\mathrm{C} / \mathrm{N}$ ratio (Coleman et al., 1989).

The total-N levels under the different systems in two depths evaluated ranged from 0.6 to $2.38 \mathrm{~g} \mathrm{~kg}^{-1}$ (Table 3). The SOM is the soil $\mathrm{N}$ main source and, therefore, a large portion of the soil total-N is in organic form (Silva \& Mendonça, 2007; Aratani et al, 2009). Thus, obviously, the soil total-N levels presented similar SOM dynamics, with greater amounts in the $0.0-0.1 \mathrm{~m}$ layer and a reduction of until $42 \%$ with increasing depth, except in soils under 


\section{Macrothink

CT, not being observed significant difference between layers in this system. In the 0.0-0.1 m layer, the systems showed no difference in the total-N contents, while the total-N levels in the lower layer were higher in soils under CT $\left(1.80 \mathrm{~g} \mathrm{~kg}^{-1}\right)$ and NT $\left(1.44 \mathrm{~g} \mathrm{~kg}^{-1}\right)$ and smaller under FV (1.01 $\left.\mathrm{g} \mathrm{kg}^{-1}\right)$ and PAST $\left(0.6 \mathrm{~g} \mathrm{~kg}^{-1}\right)$.

\subsection{Inorganic $N$}

The ratio of inorganic $\mathrm{N}$ fractions study, in addition to revealing the $\mathrm{N}$ form that predominates in the soil, assists in the events evaluation that occur most frequently under different uses and management systems, and may reveal from the greater role of nitrifying microorganisms to greater organisms community activity that perform nitrate to ammonia dissimilar reduction.

Ammonium concentrations in soils ranged from 5.17 to $17.53 \mathrm{mg} \mathrm{kg}^{-1}$, with a significant decrease between layers only in soils under FV (Table 3). This variation, in a FV environment, corresponded to a significant reduction of 1.6 times in the ammoniacal $\mathrm{N}$ amount in the soil in the 0.1-0.2 $\mathrm{m}$ layer in relation to $0.0-0.1 \mathrm{~m}$. In the two layers evaluated (0.0-0.1 and 0.1-0.2 $\mathrm{m})$, ammonium concentrations was similar in soils under CT $\left(6.12 \mathrm{mg} \mathrm{kg}^{-1}\right)$, NT $(5.40 \mathrm{mg}$ $\mathrm{kg}^{-1}$ ) and PAST (6.40 mg kg $\mathrm{mg}^{-1}$ ) and lower up to 2.4 times less than the values found in the soil under FV (14.40 $\left.\mathrm{mg} \mathrm{kg}^{-1}\right)$.

The $\mathrm{NH}_{4}{ }^{+}$ions formation is the first SOM mineralization product carried out by heterotrophic microorganisms in reducing conditions (ammonification). However, as ammonium $\left(\mathrm{NH}_{4}^{+}\right)$ undergoes rapid oxidation to nitrate $\left(\mathrm{NO}_{3}{ }^{-}\right)$, the assessment of the organic $\mathrm{N}$ mineralization is revealed by quantifying ammonium $\left(\mathrm{NH}_{4}{ }^{+}\right)$and also nitrate $\left(\mathrm{NO}_{3}{ }^{-}\right)$(El-Husny, 2010). Normally, native vegetation areas, due to low fertility and acidity (low $\mathrm{pH}$ ), nitrifying microorganisms are disadvantaged, with consequent $\mathrm{N}$ in the ammoniacal form accumulation (Bijlsma; Lambers; Kooijman, 2000). In their study, Poletto, Grohs and Mundstock (2008), for example, commented on the ammonium predominance in soils under forests and in natural pastures. El-Husny (2010), also evaluated ammonium contents in soils under pasture and native forest in the same region of this study at three times of the year and identified similar behavior. Hungria (2018), found an average ammonium contents in the soil equal to $26.17 \mathrm{mg} \mathrm{kg}^{-1}$ in the $0.0-0.2 \mathrm{~m}$ layer in soil under native vegetation which was the highest average found when compared to soils under CT and up to 12 years of NT implantation, showing the greater ease of environments without interference in accumulating $\mathrm{N}$, especially in the ammoniacal form when compared to areas under agricultural production. 
Table 3. Soil total $\mathrm{N}\left(\mathrm{g} \mathrm{kg}^{-1}\right)$, ammonium $\left(\mathrm{mg} \mathrm{kg}^{-1}\right)$ and nitrate $\left(\mathrm{mg} \mathrm{kg}^{-1}\right)$ in two depths under fallow vegetation (FV), conventional tillage (CT), no-tillage (NT) and Pasture (PAST) in Brazilian Eastern Amazon

\begin{tabular}{|c|c|c|c|c|c|}
\hline \multirow[b]{2}{*}{ Depth (m) } & \multicolumn{4}{|c|}{ Use and management system of soil } & \multirow[b]{2}{*}{ Mean } \\
\hline & $\mathrm{FV}$ & $\mathrm{CT}$ & NT & PAST & \\
\hline & \multicolumn{5}{|c|}{ Total-N $\left(\mathrm{g} \mathrm{kg}^{-1}\right)$} \\
\hline $0.0-0.1$ & $1.91 \mathrm{Aa}$ & $1.91 \mathrm{Aa}$ & $2.17 \mathrm{Aa}$ & $2.38 \mathrm{Aa}$ & $2.10 \mathrm{~A}$ \\
\hline $0.1-0.2$ & $1.01 \mathrm{Bb}$ & $1.81 \mathrm{Aa}$ & $1.44 \mathrm{Ba}$ & $0.60 \mathrm{Bb}$ & $1.21 \mathrm{~B}$ \\
\hline \multirow[t]{2}{*}{ Mean } & $1.46 \mathrm{~b}$ & $1.85 \mathrm{a}$ & $1.81 \mathrm{a}$ & $1.48 \mathrm{~b}$ & 1.65 \\
\hline & \multicolumn{5}{|c|}{ Ammonium $\left(\mathrm{mg} \mathrm{kg}^{-1}\right)$} \\
\hline $0.0-0.1$ & $17.63 \mathrm{Aa}$ & $5.98 \mathrm{Ab}$ & $5.61 \mathrm{Ab}$ & $5.88 \mathrm{Ab}$ & $8.77 \mathrm{~A}$ \\
\hline $0.1-0.2$ & $11.18 \mathrm{Ba}$ & $6.26 \mathrm{Ab}$ & $5.17 \mathrm{Ab}$ & $6.93 \mathrm{Ab}$ & $7.38 \mathrm{~B}$ \\
\hline \multirow[t]{2}{*}{ Mean } & $14.40 \mathrm{a}$ & $6.12 b$ & $5.38 \mathrm{~b}$ & $6.41 \mathrm{~b}$ & 8.07 \\
\hline & \multicolumn{5}{|c|}{ Nitrate $\left(\mathrm{mg} \mathrm{kg}^{-1}\right)$} \\
\hline $0.0-0.1$ & $5.22 \mathrm{Ac}$ & $10.63 \mathrm{Ab}$ & $17.55 \mathrm{Aa}$ & $2.40 \mathrm{Ad}$ & $8.95 \mathrm{~A}$ \\
\hline $0.1-0.2$ & $2.80 \mathrm{Bb}$ & $10.15 \mathrm{Aa}$ & $11.20 \mathrm{Ba}$ & $1.92 \mathrm{Ab}$ & $6.52 \mathrm{~B}$ \\
\hline Mean & $4.01 \mathrm{c}$ & $10.39 \mathrm{~b}$ & $14.38 \mathrm{a}$ & $2.16 \mathrm{~d}$ & 7.73 \\
\hline
\end{tabular}

Means followed by the same uppercase letter in the column and lowercase letter in the row do not different by Scott-Knott test at 5\% probability level.

The soil nitrate levels ranged from 1.92 to $17.55 \mathrm{mg} \mathrm{kg}^{-1}$, with a significant decrease between layers in soils under FV and NT (Table 3). This variation, in FV environment, corresponded to a reduction of $46 \%$, while in NT it was $36 \%$ of the soil $\mathrm{N}$ nitric amounts in the layer $0.10-0.2 \mathrm{~m}$ in relation to $0.0-0.1 \mathrm{~m}$. In the $0.0-0.1 \mathrm{~m}$ layer, the decreasing order of nitrate contents was NT> CT> FV>PAST, while in the lower layer $(0.1-0.2 \mathrm{~m})$ the CT and NT systems promoted the highest levels. Regardless of the evaluated layer, the nitrate contents followed the order NT> CT> FV, with levels under PAST not differing from those found in FV.

In soils, nitrate can be reduced by assimilatory and dissimilatory processes, among them, the assimilation reduction by which microorganisms incorporate nitrate into their cells, the dissimilar reduction of nitrate to ammonium, and the denitrification of nitrate to $\mathrm{N}_{2}$ and $\mathrm{N}_{2} \mathrm{O}$, regulated for the availability of $\mathrm{O}_{2}$ (Moreira; Siqueira, 2006; Cantarella, 2007). The induction for the highest occurrence of one process or another is controlled or favored by several factors, among them soil temperature, $\mathrm{pH}$, humidity, microbiological activity, addition of nitrogen fertilizers and the system of use and management adopted. Therefore, in soils under agricultural cultivation, the highest amount of nitrate found when compared to soils that do not receive fertilizers, such as in native forest, in addition to the relationship with the processes mentioned above, can be associated with continuous nitrogen fertilization in these 
areas. Alfaia et al. (2008), observed that in an Oxisol, that the addition of urea increased the levels of nitrate in the soil. Sá et al. (2001) observed contributions of NT over time on the mineral $\mathrm{N}\left(\mathrm{N}-\mathrm{NO}_{3}{ }^{-}\right.$and $\left.\mathrm{N}-\mathrm{NH}_{4}{ }^{+}\right)$levels in the soil.

\subsection{Urease Activity}

The enzymatic activity conducts many functions of the soil ecosystem, acting as an important tool in the soil quality. The urease activity, an enzyme that releases $\mathrm{N}_{-} \mathrm{NH}_{4}{ }^{+}$, after urea hydrolysis, is an important biochemical indicator in the investigation of soil quality and assessment of the sustainability of agricultural management practices adopted (Sardans; Penuelas; Estiarte, 2008). In soils, especially under agricultural production, the lower this enzyme activity can result in reduced nitrogen availability in the form assimilable by plants (Carneiro et al., 2008).

The use and management systems have a influence on the enzymatic activity of the soil. For example, in this study, the minimum soil urease activity was $21.19 \mu \mathrm{g} \mathrm{N}-\mathrm{NH}_{4}{ }^{+} \mathrm{g}^{-1} \mathrm{soil} \mathrm{h}^{-1}$ and maximum $55.57 \mu \mathrm{g} \mathrm{N}-\mathrm{NH}_{4}{ }^{+} \mathrm{g}^{-1}$ soil $\mathrm{h}^{-1}$, with significant variation between systems in the surface layer (0.0-0.1 m). In this layer, the soils under FV $\left(55.57 \mu \mathrm{g} \mathrm{N}-\mathrm{NH}_{4}{ }^{+} \mathrm{g}^{-1} \mathrm{soil} \mathrm{h}^{-1}\right)$ and PAST (49.07 $\mu \mathrm{g} \mathrm{N}-\mathrm{NH}_{4}{ }^{+} \mathrm{g}^{-1}$ soil $\mathrm{h}^{-1}$ ) stood out, which had similar behavior in relation to the enzyme activity (Table 4). On the other hand, the average urease activity in the deepest layer (0.1-0.2 m), in general, was $28.92 \mu \mathrm{g} \mathrm{N}-\mathrm{NH}_{4}{ }^{+} \mathrm{g}^{-1} \mathrm{soil} \mathrm{h}^{-1}$, with no difference between the systems and showing a lower average in relation to to the first layer by about $27 \%$.

Table 4. Soil urease activity $\left(\mu \mathrm{g} \mathrm{N}-\mathrm{NH}_{4}{ }^{+} \mathrm{g}^{-1} \mathrm{soil} \mathrm{h}^{-1}\right.$ ) in two depths under fallow vegetation (FV), conventional tillage (CT), no-tillage (NT) and Pasture (PAST) in Brazilian Eastern Amazon

\begin{tabular}{cccccc}
\hline \multirow{6}{*}{ Depth $(\mathrm{m})$} & $\mathrm{FV}$ & $\mathrm{CT}$ & $\mathrm{NT}$ & PAST & Mean \\
\cline { 2 - 6 } & $55.57 \mathrm{Aa}$ & $21.19 \mathrm{Ac}$ & $32.14 \mathrm{Ab}$ & $49.07 \mathrm{Aa}$ & $39.50 \mathrm{~A}$ \\
$0.0-0.1$ & $32.52 \mathrm{Ba}$ & $25.81 \mathrm{Aa}$ & $31.84 \mathrm{Aa}$ & $25.53 \mathrm{Ba}$ & $28.92 \mathrm{~B}$ \\
$0.1-0.2$ & $44.04 \mathrm{a}$ & $23.50 \mathrm{c}$ & $32.00 \mathrm{~b}$ & $37.30 \mathrm{a}$ & 34.21 \\
Mean & & &
\end{tabular}

Means followed by the same uppercase letter in the column and lowercase letter in the row do not different by Scott-Knott test at 5\% probability level.

The urease activity decrease at depths is commonly evidenced in studies exploring soils under the same systems in different regions, including the amazon region (El-Husny, 2010; Hungria et al., 2019). The same authors attribute this result to the factors combination such as the SOM contents reduction in deeper layers, combined with the lack of specific substrates and the synthesis of enzymes by root excretion in the lower layers. It is possible to suggest, therefore, that in soil under CT the soil turning allows part of the SOM contents present in the surface layer to be distributed homogeneously up to the first $0.3 \mathrm{~m}$ of the soil, and thus assist in the greater performance of microorganisms that release these enzymes in the soil.

The highest urease activity in the soil was also found by Carneiro et al. (2008) in areas 
similar to this study, which, when investigating the enzyme under six different vegetation coverings in a Oxisol, registered higher averages in cerrado soils, followed by pasture $(7.7 \mu \mathrm{g}$ $\mathrm{N}_{-} \mathrm{NH}_{4}{ }^{+} \mathrm{g}^{-1}$ soil $\mathrm{h}^{-1}$ ) in layer 0.0-0.1 m. Carneiro et al. (2009) also registered a favorable environment for the activity of this enzyme in grazing soils. Cantarella (2007) attributes two possible justifications regarding the better response of urease activity in soils under native vegetation, the higher soil moisture and the higher deposition of plant residues in this system.

\section{Conclusions}

The preserved soil from forest to pasture conversion caused a reduction of $16.6 \%$ in the soil organic matter contents and $55.5 \%$ and $46 \%$ for ammonium and nitrate, respectively. Areas under no-tillage system had the capacity to accumulate soil organic matter in a similar way to the native vegetation area, as well as a high capacity to retain $\mathrm{N}$ in the soil, preferentially in the nitrate form.

\section{References}

Alfaia, S. S., Uguen, K., \& Rodrigues, M. R. L. (2008). Manejo da fertilidade dos solos na Amazônia. In: Moreira, F.M.S., Siqueira, J.O., Brussaard, L (Eds.). Biodiversidade do solo em ecossistemas brasileiros (pp.117-142). Lavras: UFLA.

Aragão, D. V., Caravalho, C. J. R., Kato, O. R., Araújo, C. M., Santos, M. T. P., \& Mourão Júnio, M. (2012). Avaliação de indicadores de qualidade do solo sob alternativas de recuperação do solo no Nordeste Paraense. Acta Amazônica, 42(1), 11-18. https://doi.org/10.1590/S0044-59672012000100002

Aratani, R. G., Freddi, O. S., Centurion, J. F., \& Andrioli, I. (2009). Qualidade física de um Latossolo Vermelho acriférrico sob diferentes sistemas de uso e manejo. Revista Brasileira de Ciência do Solo, 33(3), 677-687. https://doi.org/10.1590/S0100-06832009000300020

Bayer, C., Spagnollo, E., Wildner, L. P., Ernani, P. R., \& Alburqueque, J. A. (2003). Incremento de carbono e nitrogênio em um Latossolo pelo uso de plantas estivais para $\begin{array}{lllll}\text { cobertura do } & \text { Solôncia } & \text { Rural, } & 33(3), & \text { 469-475. }\end{array}$ https://doi.org/10.1590/S0103-84782003000300012

Bijlsma, R. J., Lambers, H., \& Kooijman, S. A. (2000). Dynamic whole plant model of integrated metabolism of nitrogen and carbon. 1. Comparative ecological implications of ammonium-nitrate $\quad$ interactions. $\quad$ Plant $\quad$ Soil, $\quad 220, \quad 49-69$. https://doi.org/10.1023/A:1004779019486

Campana, M., Bertolote, L. E. M., Bernardi, A. C. C., Oliveira, P. P. A., \& Moraes, J. P. G. (2008). Volatilização de amônia em pastagem de capim-Tanzânia fertilizada com mistura de uréia e zeólita. São Carlos - SP: Embrapa Pecuária Sudeste. (Circular Técnica).

Cantarella, H. (2007) Nitrogênio. In: Novais, R.F., Alvarez, V.V.H., Cantarutti, R.B., Neves, J.C.L. (Ed.). Fertilidade do solo (pp.375-470). Viçosa: Sociedade Brasileira de Ciência do Solo.

Cantarella, H., \& Trivelin, P. C. O. (2001). Determinação de nitrogênio total em solo. In: Raij, 
B. V., Andrade, J. C., Cantarella, H., Quaggio, J.A. (Ed.). Análise química para avaliação da fertilidade de solos tropicais. Instituto Agronômico de Campinas, Campinas, São Paulo.

Carneiro, M. A. C., Siqueira, J. O., Moreira, F. M. S., \& Soares, A. L. L. (2008). Carbono orgânico, nitrogênio total, biomassa microbiana e atividade microbiana do solo em duas cronossequências de reabilitação após mineração de bauxita. Revista Brasileira de Ciência do Solo, 32(2), 621-632. https://doi.org/10.1590/S0100-06832008000200017

Carneiro, M. A. C., Souza, E. D., Reis, E. F., Pereira, H. S., \& Azevedo, W. R. (2009). Atributos físicos, químicos e biológicos de solo de cerrado sob diferentes sistemas de uso e manejo. Revista Brasileira de Ciência do Solo, 33, 147-157. https://doi.org/10.1590/S0100-06832009000100016

Cerri, C. E. P., Feigl, B. J., \& Cerri, C. C. (2008). Dinâmica da matéria orgânica do solo na Amazônia. In: Santos, G.A.; Silva, L.S.; Canellas, L.P.; Camargo, F.A.O. (2nd ed). Fundamentos da matéria orgânica do solo: ecossistemas tropicais e subtropicais. Porto alegre: Metrópole.

Coleman, D. C., Oades, J. M., \& Uehara, G. (1989). Dynamics of organic matter in tropical ecossystems. Niftal Project, University Hawaí Press. 249 pp.

Cordeiro, L. A. M., \& Hoek, J. B. V. D. (2007). Nitrogênio na cultura do milho sob sistema plantio direto. Revista Factuciência, 13(7), 27-54.

Costa, O. V., Costa, L. M., Fontes, L. E. F., Araujo, Q. R., Ker, J. C., \& Nacif, P. G. S. (2000). Cobertura do solo e degradação de pastagens em área de domínio de Chernossolos no sul da Bahia. Revista Brasileira de Ciência do Solo, 24(4), 843-856. https://doi.org/10.1590/S0100-06832000000400016

El-Husny, J. C. (2010). Avaliação de indicadores de qualidade de um Latossolo Amarelo em sistemas de integração de lavoura-pecuária no município de Paragominas, estado do Pará. (Tese de Doutorado). Universidade Federal Rural da Amazônia, Belém.

Fageria, N. K., Baligar, V. C., \& Jones, C. A. (2011). Growth and mineral nutrition of field crops (3rd ed). Boca Raton, FL, USA: CRC Press. https://doi.org/10.1201/b10160

Hungria, L. C. (2018). Indicadores biológicos de qualidade do solo em uma cronossequência sob sistema plantio direto na Amazônia oriental. (Dissertação de mestrado). Universidade Federal Rural da Amazônia. Can also be found at repositorio.ufra.edu.br/jspui/handle/123456789/467

Hungria, L. C., El-Husny, J. C., Silva Junior, M. L., \& Melo, V. S. (2019). Atividade da urease no solo sob influência do tempo de implantação do sistema plantio direto. In: VIII Simpósio de Estudos e Pesquisas em Ciências Ambientais na Amazônia. Can also befoundat: http://paginas.uepa.br/pcambientais/simposio/anais_resumos_simposio_2019.pdf

Keeney, D. R. (1982). Nitrogen: availability Índices. In: Page, A.L., Miller, R.H., Keeney, D.R. (2a ed.). Methods of soil analysis: Chemical and microbiological properties. American Society of Agronomy, Madison, Wiscosin. 
Lisboa, B. B., Vargas, L. K., Silveira, A. O. D., Martins, A. F., \& Selbach, P. A. (2012). Indicadores microbianos de qualidade do solo em diferentes sistemas de manejo. Revista $\begin{array}{llllll}\text { Brasileira de } & \text { Ciência } & \text { 33-43. }\end{array}$ https://doi.org/10.1590/S0100-06832012000100004

Lopes, E. L. N., Fernandes, A. R., Teixeira, R. A., Souza, E. S., \& Ruivo, M. L. P. (2015). Soil attributes under different crop management systems in a Amazon Oxisols. Bragantia, 74(4), 428-435. https://doi.org/10.1590/1678-4499.03914.

Lourente, E. R. P., Silva, E. F., Mercante, F. M., Serra, A. P., Peixoto, P. P. P., Sereia, R. C., ... Cortez, J. W. (2016) Agricultural management systems effect on physical, chemical and microbial soil properties. Australian Journal of Crop Science, 10(5), 683-692. https://doi.org/10.21475/ajcs.2016.10.05.p7410.

Moreira, F. M. S., \& Siqueira, J. O. (2006). Microbiologia e bioquímica do solo (2nd ed.). Lavras: UFLA. pp. 729.

Poletto, N., Grohs, D. S., \& Mundstock, C. M. (2008). Flutuação diária e estacional de nitrato e amônio em um Argissolo Vermelho distrófico típico. Revista Brasileira de Ciência do Solo, 32(4). https://doi.org/10.1590/S0100-06832008000400026

Rangel, O. J. P., \& Silva, C. A. (2007). Estoques de carbono e nitrogênio e frações orgânicas de Latossolo submetido a diferentes sistemas de uso e manejo. Revista Brasileira de Ciência do Solo, 31(6), 1609-1623. https://doi.org/10.1590/S0100-06832007000600037

Rodrigues, T. E., Silva, R. C., Silva, J. M. L., Oliveira, R. C., Gama, J. R. N. F., \& Valente, M. A. (2003). Caracterização e classificação dos solos do município de Paragominas, estado do Pará. Belém: Embrapa Amazônia Oriental.

Sá, J. C. M., Cerri, C. C., Lal, R., Dick, W. A., Venzke Filho, S. P., Piccolo, M., \& Feigl, B. (2001). Organic matter dynamics and sequestration rates for tillage cronosequence in a Brasilia Oxisol. Soil Science Society of America Journal, 65(5), 1486-1499. https://doi.org/10.2136/sssaj2001.6551486x

Sardans, J, Penuelas, J., \& Estiarte, M. (2008). Changes in soil enzymes related to C and N cycle and in soil $\mathrm{C}$ and $\mathrm{N}$ content under prolonged warming and drought in a Mediterranean $\begin{array}{lllll}\text { shrubland. } \quad \text { Applied } & \text { Soil 223-235. }\end{array}$ https://doi.org/10.1016/j.apsoil.2007.12.011.

Silva Júnior, A. C., Ruivo, M. L. P., Silva, C. M., \& Okumura, R. S. (2018). Variação sazonal dos atributos do solo em plantios de palma de óleo na Amazônia Oriental. Revista Brasileira de Ciências Agrárias, 13(2), 1-8. https://doi.org/10.5039/agraria.v13i2a5531

Silva, I. F., \& Mielniczuk, J. (1997) Ação do sistema radicular de plantas na formação e estabilidade de agregados do solo. Revista Brasileira de Ciência do Solo, 21(1), 113-117. https://doi.org/10.1590/S0100-06831997000300012

Silva, I. R., \& Mendonça, E. S. (2007). Matéria orgânica do solo. In: NOVAIS, R.F.; Alvarez V., V.H.; Barros, N.F. de; Fontes, R.L.F., Cantarutti, R.B., Neves, J.C.L. (Ed.). Fertilidade do 
solo (pp 275-374). Viçosa: Sociedade Brasileira de Ciência do Solo.

Siqueira Neto, M., Piccolo, M. C., Venzke, S. P., Feigl, B. J., \& Cerri, C. C. (2010). Mineralização e desnitrificação do nitrogênio no solo sob sistema plantio direto. Bragantia, 69(4), 923-936. https://doi.org/10.1590/S0006-87052010000400019

Tabatabai, M. A., \& Bremner, J. M. (1972). Assay of urease activity in soil. Soil Biology Biochemistry, 4(4), 479-487. https://doi.org/10.1016/0038-0717(72)90064-8

Ussiri, D. A. N., \& Lal, R. (2009). Long-term tillage effects on soil carbon storage and carbon dioxide emissions in continuous corn cropping system from an Alfisol in Ohio. Soil and Tillage Research, 104, 39-47. https://doi.org/10.1016/j.still.2008.11.008

Walkley, A., \& Black, I. A. (1934). An examination of the Degtjareff method for determining soil organic matter and a proposed modification of the chromic acid titration method. Soil Science. 37(1), 29-38. https://doi.org/10.1097/00010694-193401000-00003

Webster, J. R., Knoepp, J. D.; Swank, W. T., \& Miniat, C.F. (2016). Evidence for a regime shift in nitrogen export from a forested watershed. Ecosystems. 19(5), 881-895. https://doi.org/10.1007/s10021-016-9974-1

Yang, J. E., Skogley, E. O., Schaff, B. E., \& Kim, J. J. (1998). Simple spectrophotometric determination of nitrate in water, resin and soil extracts. Soil Science Society of America Journal, 62(4) 1108-1115. https://doi.org/10.2136/sssaj1998.03615995006200040036x

\section{Copyright Disclaimer}

Copyright for this article is retained by the author(s), with first publication rights granted to the journal.

This is an open-access article distributed under the terms and conditions of the Creative Commons Attribution license (http://creativecommons.org/licenses/by/4.0/). 